\title{
A unificação das polícias no Brasil
}

\author{
HÉLIO BICUDO
}

$\mathrm{O}$

TEMA segurança pública está hoje na ordem do dia. Realmente, na amplitude do horizonte dos Direitos Humanos, os instrumentos que devem assegurar a segurança do povo assumem papel relevante. E essa segurança deveria encontrar, nos órgãos policiais, que constituem a primeira linha no combate à criminalidade, o seu principal ponto de apoio.

O homem comum, seja desta ou daquela classe social - enquadradas nas estatísticas, nas chamadas classes $\mathrm{A}, \mathrm{B}, \mathrm{C}$ e $\mathrm{D}$, conforme o grau de riqueza, de pobreza ou de instrução - quer que seus filhos possam ir à escola sem temor; quer ir para o trabalho ou desfrutar do lazer sem preocupações maiores com a sua segurança ou a dos seus. Entretanto, diante das reconhecidas omissões do Estado nesse setor, as classes alta e média alta enclausuram-se nos condomínios fechados; à falta de meios para se socorrer de uma despreparada segurança privada, os demais setores da sociedade expõem-se aos riscos da violência armada pelo desemprego e pela miséria, quando não pela própria polícia, o que não é incomum.

Na verdade, a segurança pública não é apenas uma questão de polícia. Mas, sem dúvida, cabe a ela uma participação relevante na preservação e na manutenção do que poderíamos chamar de paz pública.

No Brasil, entretanto, lamentavelmente, a polícia - como existe hoje, compartimentalizada em polícia militar e polícia civil - não atende às necessidades da sociedade, relativamente à sua segurança.

Trata-se de um modelo esgotado e que fora montado, nos anos da ditadura militar, para a segurança do Estado, na linha da ideologia da segurança nacional, segundo a qual quem não é amigo é inimigo e como tal deve ser tratado, linha de atuação que qualificou, naquele período da nossa história, a atuação policial.

Pois bem, para que se chegue a uma conclusão sobre a problemática, que hoje é um desafio, da unificação das polícias, convém lembrar como chegamos à situação atual, de duas polícias, uma militar, encarregada do policiamento ostensivo e outra civil, com atribuições de polícia investigativa. 
No final do século passado e no início deste, com a República e o modelo federativo adotado, as antigas províncias, que se constituíram em estados autonômos, trataram desde logo de organizar-se para preservar aquele modelo e a independência conquistada. Afinal, as Forças Armadas, então representadas pelo Exército e pela Marinha, eram corporações nacionais a serviço da União. Contra elas era preciso antepor dispositivos de dissuasão, capazes de dificultar ou mesmo impedir que o poder central se tornasse incontestável, anulando dessa forma a autonomia das unidades federadas.

Foi assim que se constituíram pequenos exércitos estaduais chamados "Forças Públicas”, "Brigadas”, ou qualquer outra designação que ainda tenham.

Em São Paulo, o governo Jorge Tibiriçá organizava, já em 1891, a Força Pública Estadual, com o objetivo de defesa do poder instituído em nível estadual, da preservação das relações existentes com os Estados membros e da defesa dos interesses regionais. Na verdade, porém, se no plano federal as Forças Armadas serviam aos interesses dos grupos oligárquicos hegemônicos, no plano estadual as "forças públicas" representavam os mesmos interesses, que correspondiam, nesse caso, aos partidos políticos regionais. A sua missão era, num primeiro plano, defender o governo local contra os excessos da União, e as classes dominantes contra eventuais manifestações de protesto das classes populares.

Contra a organização estritamente militar da Força Pública e de sua utilização limitada aos problemas relativos à manutenção das instituições ou à defesa da dignidade da Pátria, encontram-se interessantes manifestações como a que se lê em carta endereçada por um leitor ao jornal $O$ Estado de $S$. Paulo, publicada a 19 de março de 1898, na qual o missivista, mesmo não se dizendo contrário à organização militar dos batalhões da Força Pública, porque "a organização militar pressupõe disciplina, sem a qual não há polícia", sentia-se, entretanto um contribuinte ludibriado, não compreendendo e não admitindo "que toda a Força Pública esteja por aí aquartelada, como se fosse um exército em tempo de paz, enquanto nós, cá fora, andamos expostos à sanha dos assassinos e à ousadia sempre crescente dos ladrões".

Tendo em consideração que se fazia necessária uma organização realmente funcional dessas corporações, providenciou-se, em São Paulo, a vinda de uma missão do Exército francês, para dar instrução adequada aos seus componentes.

Em relatório apresentado pelo mesmo Jorge Tibiriçá, em 1907, salienta-se o fato, por solicitação do governo do estado de São Paulo, de terem vindo distintos oficiais do Exército francês - cujo trabalho foi enaltecido, 
posteriormente, por vários presidentes do estado - para elevar o nível moral e intelectual da Força Pública e ministrar-lhe os mais modernos ensinamentos da arte militar em ordem a tornar essa força um órgão de defesa social, eficiente e poderoso.

A Força Pública de São Paulo, cujos efetivos atingiram níveis superiores ao do próprio Exército - em 1930 a Força Pública contava com 14.224 homens, ao passo que o Exército dispunha apenas de 3.675 - chegando a ter artilharia de campo e até mesmo a dispor de aviões de combate. Serviu ela de núcleo de base aos movimentos contra o poder central deflagrados em 1924 e 1932.

A partir deste último, com a vitória do governo central, começa o seu declínio, pois, diante do Estado unitário que se ia formando e que encontrou sua definição em 1937 com o estabelecimento do que se chamou o "Estado novo" - à feição totalitária dos Estados nazifascistas - não havia mais como falar em autonomia dos estados e, portanto, em forças dissuasórias do poder central.

Se a Força Pública era ainda útil como instrumento de contenção popular, ela ia perdendo para as Forças Armadas, e para o Exército em especial, a posição antes desfrutada. Para evitar rebeliões contra o poder central, ela foi se despindo de sua autonomia no que respeita ao armamento à sua disposição e às dimensões de sua organização. Em pouco tempo, o seu efetivo não passava de uma fração no conjunto das Forças Armadas, agora mais poderosas, acrescidas de uma nova e depois ativa força aérea.

Cedendo funções, ela buscava outras, que encontrava ocupadas pela polícia civil: a guarda civil e a polícia civil propriamente dita, esta sem uniforme.

A questão que começava então a ser posta, das funções policiais da Força Pública, foi objeto de intensos debates que se travaram segundo a atuação propriamente policial da milícia.

Desde que ela perdera o fundamento mesmo de sua existência, era óbvio que o próprio governo do estado tomasse a iniciativa de buscar uma solução para o problema. Afinal, eram milhares de homens que participavam de grande fatia do orçamento e que não tinham funções. Mas o seu equacionamento nem sempre encontrou, das próprias autoridades governamentais, o melhor enfoque.

Em 1956, na gestão Jânio Quadros no governo de São Paulo, nomearam-se tenentes e capitães da Força Pública para o desempenho de funções 
precípuas da polícia civil. A esse propósito, saía a campo o jornal O Estado de S. Paulo a profligar a medida. Acentuando o caráter militar da Força Pública, editorial desse jornal de 21 de novembro de 1956 salientava que a milícia estava sem funções e acrescentava: "inerte como se acha, não somente causa inquietação entre seus integrantes, que desejam trabalhar, como ainda absorve $60 \%$ do orçamento destinado à Secretaria de Segurança Pública”. E “enquanto isso, o policiamento de São Paulo se revela precário, muito longe das necessidades de uma cidade que é mais do que isso, porque é uma grande metrópole cosmopolita, e que exige rigor no serviço de vigilância por causa do número elevado de maus elementos que aqui pululam".

Essa luta se acirrou em mais de um episódio. Daí a tentativa de reunirse num corpo só, de características eminentemente civis, a Força Pública e a Guarda civil, permanecendo a polícia civil com seus delegados e investigadores nas tarefas da chamada polícia judiciária, de caráter repressivo, pois sua ação viria após as práticas delituosas, oferecendo as provas necessárias aos procedimentos judiciais.

Foi ainda no governo Jânio Quadros que se chegou a constituir um grupo de trabalho que, sob a coordenação de um membro do Ministério Público, esteve na Inglaterra, estagiando por vários meses na Scotland Yard. Esse grupo de trabalho ofereceu extenso relatório sobre as observações feitas e apresentou uma proposta de unificação das polícias a qual, por questões corporativas, não pôde prosperar.

O golpe de 1964 resolveu o problema, segundo as concepções da ideologia da segurança nacional, buscando a criação de uma força militar auxiliar, adestrada para responder aos atos da guerrilha desencadeada por organizações que contestavam, pela via da luta armada, a ditadura então estabelecida.

Em São Paulo fundiram-se a Guarda Civil e a Força Pública e o resultado foi a sua Polícia Militar, guardando a mesma feição de suas congêneres nos demais estados da Federação, onde aconteceram fusões semelhantes.

A Polícia Militar substituiu, digamos, as "Forças Públicas" e as "Guardas Civis", aquelas nos enfrentamentos populares e estas no policiamento preventivo, sob controle direto do Exército.

É assim que o decreto-lei 667, de 2 de julho de 1969, atribuiu ao Ministério do Exército o controle e a coordenação das Polícias Militares por intermédio do Estado Maior do Exército em todo o território nacional, pelos exércitos e comandos militares de áreas nas respectivas jurisdições (sic) pelas regiões militares nos territórios nacionais, sendo o cargo de inspetor 
geral das Polícias Militares desempenhado por um general de brigada, em serviço ativo.

A centralização das Polícias Militares, com sua subordinação direta ao Exército, foi uma decisão diretamente ligada às dificuldades das Polícias Civis em lidarem com as tarefas impostas pela consolidação do regime autoritário, bem como ao desempenho das antigas forças policiais estaduais - Forças Públicas ou Brigadas - na luta armada posta em cena por alguns setores da oposição.

O governo militar, a partir do golpe de 1964, tratou, como se viu, de transformar as antigas milícias em forças auxiliares do Exército, em obediência mesmo, repita-se, aos preceitos insertos na ideologia da segurança nacional.

Assim, o comando geral das Polícias Militares passou a ser exercido por oficiais superiores do Exército e só excepcionalmente, desde que houvesse anuência do Ministro do Exército, por oficial da própria tropa, conforme dispõe o parágrafo $5^{\circ}$ do artigo $6^{\circ}$, do decreto-lei 667 de 2 de julho de 1969 , ainda em vigor.

E o regulamento 200, aprovado pelo decreto 66.862, de 8 de julho de 1970, determina que as Polícias Militares, "para emprego em suas atribuições específicas ou como participantes da defesa interna ou da defesa territorial, ficarão diretamente subordinadas aos comandantes do Exército ou comandantes militares da área $\left(\operatorname{artigo~} 4^{\circ}\right)$.

Aliás, toda a legislação posterior ao golpe de 64 teve como tônica a preocupação de subordinar as milícias estaduais ao comando geral e central das Forças Armadas, donde se pode concluir, ainda hoje, que as Polícias Militares não são corporações subordinadas aos governos estaduais, mas diretamente sujeitas, hierárquica e operacionalmente, ao Exército; que o Estado Maior do Exército exerce, ainda, fiscalização administrativa sobre as Polícias Militares, mediante a atuação da Inspetoria Geral das Polícias Militares (artigo 23 e parágrafo $3^{\circ}$ do regulamento 200); e mais, que esses vínculos de subordinação hierárquica, operacional e administrativa são permanentes.

As novas Polícias Militares, além de intervirem especificamente na luta armada dos anos 60 e 70 não deixaram, entretanto, de exercer o seu papel de força de contenção das manifestações de descontentamento nas cidades e no campo, de dissenso civil - como assinala Paulo Sérgio Pinheiro em Polícia e crise politica: o caso das polícias militares - enquadrado ou não por organizações políticas, como passeatas, greves, comícios, protestos, ocupações de terra etc. 
As Polícias Militares passam, no momento em que se interrompe a guerrilha, ao enfrentamento do crime convencional. Vão desenvolver, então, sua guerra contra o crime, utilizando as mesmas práticas e valendo-se da mesma impunidade. Os métodos e o equipamento utilizado nas operações policiais apagaram a linha de separação que havia entre operações militares e operações policiais. Como as políticas públicas não têm tido condições de encontrar soluções para a criminalidade, o crime é resolvido mediante a utilização de métodos militares, sob a inteira responsabilidade do aparelho militar central.

O papel das Polícias Militares aparece portanto bastante claro, qualificando as populações marginalizadas, as mais expostas a essa guerra, com o conceito - advindo ainda da ideologia da segurança nacional - de inimigo interno, que cumpre eliminar.

É bem de ver que o quantum de violência que se contém nessa atitude - a extravasar nas prisões ilegais, nas torturas e nos homicídios desde então praticados - não poderia encontrar limites na atuação do Poder Judiciário comum ao aplicar, pelos seus juízes e tribunais, o Código Penal, quando tipifica as lesões corporais, o homicídio, o seqüestro, a tortura, a corrupção e o arbítrio das autoridades públicas.

A violência como método aparece no número sempre crescente das eliminações indiscriminadas nas cidades e no campo.

Em São Paulo, numa curva ascendente, passamos de três centenas de homicídios, no início dos anos 80, para mais de mil em 92, dados esses divulgados pela própria Polícia Militar em outubro desse mesmo ano. Nesses totais não foram computados os 111 mortos no massacre do Carandirú e, por igual, aqueles que não constam dos registros do Instituto Médico Legal porque foram assassinados e enterrados nas quebradas da periferia da cidade.

Isto aconteceu e ainda acontece, como assinala pesquisa recente levada a efeito pela Ouvidoria da polícia sobre o uso da força letal por policiais de São Paulo no ano de 1999, pela qual se verifica um aumento significativo, como adiante se demonstrará, da quantidade de mortes provocadas pela atuação policial nesse ano, a maior desde 1992, porque além do fato de que, ao exercerem uma atividade essencialmente civil, o fazem segundo concepções militares - na guerra vale tudo - estão os policiais militares sujeitos a uma justiça especial, rigorosa quando se trata de infrações disciplinares, mas complacente quando julga os chamados crimes decorrentes das atividades de policiamento. 
Quando damos os primeiros passos para a democratização do Brasil, é sem dúvida ponto importante a democratização de sua polícia, para que ela sirva ao povo e não ao Estado.

Desmilitarizadas - e além disso não pode ir ao legislador federal, como os Estados não podem manter forças militares autônomas - a solução será a unificação das polícias, sem o desperdício de meios materiais e de recursos humanos como hoje acontece: duplicidade de imóveis, de meios de transporte e, sobretudo, de comunicações, de pessoal burocrático etc.

A nova polícia deverá ser hierarquizada e terá disciplina, aliás como acontece com o funcionalismo em geral. Terá um ramo uniformizado para as tarefas de policiamento preventivo e outro, em trajes civis, para os trabalhos de investigação criminal. Terá um grupo treinado para, sem apelar para a violência, atuar como força de dissuasão de distúrbios ocorrentes. Será uma polícia que, ademais, deverá conhecer as pessoas às quais atende e ser por elas conhecida. Enfim, uma polícia democrática, voltada para os reais interesses do povo no que respeita à segurança, para que esse povo tão sofrido possa trabalhar e ter lazer, ir à escola, reunir-se e participar politicamente do processo de seu aperfeiçoamento.

$\mathrm{O}$ artigo $144, \mathfrak{S} 4^{\circ}, 5^{\circ}$ e $6^{\circ}$ da Constituição Federal institucionalizou o modelo imposto pelo decreto 1.072, de 30 de dezembro de 1969, que extinguiu as guardas civis em todo o país, anexando-as às força militares estaduais existentes, então chamadas genericamente de "Forças Públicas".

A partir daí, criadas as Polícias Militares, sujeitas em sua organização, planejamento, armamento e comando à Inspetoria das Polícias Militares, órgão do Estado Maior do Exército, atuaram decididamente na luta contra quantos, pessoalmente ou participando de organizações extralegais, se opunham à ditadura militar e almejavam uma opção democrática para o Brasil. A Polícia Militar, treinada e organizada para o combate a essas pessoas ou grupos, constituía uma polícia do Estado, na defesa da chamada segurança nacional, segundo a concepção imposta pelos embates entre EUA e União Soviética às ditaduras que se foram instituindo na América Latina sob inspiração norte-americana, qualificada pela oposição Leste/Oeste.

À medida que o país se foi democratizando, as Polícias Militares guardaram, contudo, sua qualificação estritamente militar. E o Congresso Constitucional, eleito em 1986, não soube inovar e institucionalizou as corporações militares dos estados como um dos organismos responsáveis pelo policiamento preventivo; e fez mais, pois manteve um sistema judiciário corporativo, responsável, em larga medida, pela impunidade que ainda 
acoroçoa a violência que deles emana na sua atuação enquanto polícia ostensiva.

Sob esse aspecto, os constituintes de 1986 não quiseram ou, provavelmente, não puderam enfrentar o desafio de desmontar por inteiro os fundamentos de uma ditadura que então se desfazia. Ao invés, consolidaram a existência de uma Polícia Militar autoritária e arbitrária, cuja atuação contava com a complacência de uma justiça corporativa que tornava impunes as violações das normas de direitos humanos contempladas, explicitamente, no pórtico da Constituição promulgada em 1988, como o fundamento mesmo do Estado Democrático de Direito.

A propósito da atuação dessa justiça das Polícias Militares, o Centro Santo Dias de Defesa dos Direitos Humanos, da Arquidiocese de São Paulo, realizou uma pesquisa sobre os primeiros dez anos de atuação da Justiça militar da Polícia Militar de São Paulo, quando constatou que não havia, por esse órgão, julgamentos imparciais, mas decisões que resvalavam para a mais absoluta impunidade. Os índices de impunidade então apurados chegavam ao patamar dos 95\% dos casos examinados. Pois bem, não obstante os dados que vêm sendo divulgados a respeito, por esse e por outros estudos, teima-se, como veremos mais adiante, em manter a mesma estrutura de responsabilização pelos crimes praticados por policiais militares em suas atividades de policiamento, estrutura essa montada pelos interesses, hoje ultrapassados, de uma polícia que, insista-se, fora instituída sob a inspiração da ideologia da segurança nacional.

E, deixando de ir a fundo na questão, busca-se disfarçar a inoperância do sistema atual, apelando-se para argumentos que vão na linha de deixar tudo como está: não faz muito tempo, o general Alberto Cardoso, ministro chefe do Gabinete de Segurança Institucional da Presidência da República, dizia que "não se deve correr o risco de soluções afastadas da realidade nacional, inspiradas apenas em modelos de outros países ou carentes da devida discussão em fórum apropriado como o Congresso Nacional" (cf. Pobreza, cidadania e segurança, editora José Olímpio).

Ora, o que é a realidade nacional, perguntamos nós? Aquela da ditadura a qual o general serviu, onde a vontade do chefe se sobrepunha à verdade da comunidade, ou a maré montante de violência que se avoluma na medida que o Brasil mais e mais se atrela à política imperialista do Fundo Monetário e do Banco Mundial e, em conseqüência, vê o aumento progressivo da fome e da miséria de tantos e o enriquecimento de tão poucos, às custas dos maiores sacrifícios de uma classe trabalhadora que se desespera na busca de sua sobrevivência? 
A verdade é que os modelos adotados pelos países do primeiro mundo aconselham uma polícia civil a serviço do povo. Mas o general-ministro prefere, sem dúvida, a militarização das polícias. É o que se lê, ainda, no seu pronunciamento no fórum nacional, organizado por João Paulo dos Reis Veloso e Roberto Cavalcanti de Albuquerque. À pergunta "se a atividade de segurança pública é atividade militar" ele responde que, segundo a doutrina de diversos países, as polícias podem ser militares e cita como exemplo França, Itália,

\section{países do primeiro mundo aconselham uma polícia civil} a serviço do povo ... Portugal e Chile, onde existem corporações militares com atribuições policiais. Tenha-se em vista que a pergunta deveria ter sido outra: a função policial é civil ou militar? E, depois: os militares devem exercer funções policiais civis?

Ademais, os exemplos citados não abonam a tese do general-ministro, porque, na França, a gendarmerie é apenas um resquício tradicional, pois a polícia que conta é a polícia nacional, que é civil, e tanto na França quanto na Itália, ou em Portugal, os policiais são julgados nos crimes de função pela Justiça Comum. Quanto ao Chile e outros países da América Latina - que mantêm a "Polícia Militar" -, ressalte-se que a Comissão Interamericana de Direitos Humanos tem feito reiteradas recomendações no sentido de que entreguem, com exclusividade, as atividades de policiamento às autoridades civis. Isto porque tal Comissão tem constatado que os índices de violações de direitos humanos se avolumam e restam, todavia, impunes quando se entrega a segurança pública ao mando militar. Nesse sentido, advirta-se que as recomendações da Comissão Interamericana de Direitos Humanos devem ser cumpridas pelos países que firmaram e ratificaram a Convenção Americana de Direitos Humanos, como é o caso do Brasil, pois, segundo a Convenção de Viena sobre o Direito dos Tratados, os Estados não se podem esquivar daquilo que convencionaram em nível internacional, devendo cumpri-lo de "boa-fé".

O ministro Alberto Cardoso declara, ainda, que o fórum apropriado para a discussão dessa problemática é o Congresso Nacional. Sem dúvida que o é, mas em última instância, pois o lugar e o momento apropriados são os da sociedade civil, que procura encontrar caminhos para sua segurança, independentemente dos interesses corporativos que se instalam no próprio governo, seja no Executivo, seja no Parlamento. Neste último, os lobbies, alimentados pela complacência do Executivo ou até mesmo pelos interesses daqueles que nele se sobrepõem aos interesses populares, têm sistematicamente impedido que se avance no sentido da construção de uma polícia realmente próxima do povo e que atenda às suas demandas. 
O resultado dessa atitude, ao esquecer os interesses maiores da comunidade dos brasileiros, aí está, com o crescimento, quase sem peias, da violência policial em todo o país. Como já pontuou o ouvidor da polícia de São Paulo, o sociólogo Benedito Domingos Mariano, por força de um regimento disciplinar que segue as linhas do RDE (Regulamento Disciplinar do Exército), as infrações interna corporis são punidas com rigor, deixando-se impunes os delitos cometidos contra o povo, fora dos muros dos quartéis.

A pesquisa já referida, realizada pelo Centro Santo Dias de Defesa dos Direitos Humanos da Arquidiocese de São Paulo, quando dos 10 anos de justiça militar das Polícias Militares neste estado, constatou uma impunidade de cerca de $95 \%$ dos delitos cometidos nas ruas, contra civis, pelos milicianos.

Essa espantosa impunidade, mola da violência, como já se acentuou, determinou a apresentação de projetos de lei com o objetivo de obter a transferência da competência do processo e julgamento de crimes cometidos pela Polícia Militar em funções de policiamento à Justiça Comum. Entretanto, nesse campo muito pouco se avançou: apenas o julgamento dos crimes dolosos contra a vida passaram à alçada da Justiça Comum. Todo o mais, inclusive as investigações sobre aqueles delitos, permanece nas mãos dos órgãos policiais militares: os conselhos de justificação e as auditorias. E isto se deve a que os órgãos do Poder Executivo Federal não se dispõem a abrir mão do poder que detêm sobre um efetivo militar muito próximo e até mesmo superior aos das Forças Armadas. Os lobbies nesse sentido paralisaram, no Senado Federal, projeto aprovado na Câmara dos Deputados, que busca alcançar a maior abrangência da competência da Justiça Comum na elucidação e no julgamento dos crimes praticados por policiais militares em suas atividades de policiamento, aliás, na forma do decidido pelo Supremo Tribunal Federal, cristalizado em súmula, que determinava a submissão de todos os crimes cometidos por PMs no exercício de suas atribuições policiais à Justiça Comum.

A esse propósito convém lembrar que a CPI que investigou, em 1991, a eliminação de crianças e jovens em todo o país, constatou que a responsabilidade por todo esse extermínio cabia, na

a violência crescia sua maior parte, às Polícias Militares e que a violência crescia na mesma proporção da imna mesma proporção punidade que beneficiava os milicianos, pois da impunidade .... o processo investigativo e o julgamento desses casos cabiam a uma justiça especial das próprias corporações policiais militares. Não foi por outro motivo que a CPI resolveu oferecer projeto para que se retornasse ao sistema que vigorara até 
abril de 1979, quando, por reiteradas decisões do Supremo Tribunal Federal, o processo e julgamento dos crimes cometidos por oficiais e praças das Polícias Militares, nas atividades de policiamento, que são consideradas atividades eminentemente civis, eram da competência da Justiça Comum. Foi, aliás, a partir daquela data, com a edição do chamado "pacote de abril", que se ampliou a competência da Justiça militar das PMs, para abranger também esses delitos.

Diante desse quadro, para sujeitar as PMs, na prática de crimes contra civis, à Justiça Comum apresentou, aquela CPI, projeto de lei à consideração da Câmara dos Deputados. Esse projeto recebeu emendas e substitutivos, que visavam a aperfeiçoá-lo. A Câmara, entretanto, por proposta do então deputado Genebaldo Corrêa, líder do PMDB, aprovou emenda aglutinativa, amplamente defendida pelo então deputado Ibsen Pinheiro, gozando à época de grande prestígio por ter comandado a batalha do impeachment do expresidente Fernando Collor, a qual ampliava a competência da Justiça Comum apenas para o julgamento dos "crimes dolosos contra a vida" cometidos por policiais militares. Sem qualquer justificativa mais racional, permaneceriam sob a jurisdição da Justiça militar das PMs os espancamentos, as lesões corporais, os homicídios culposos, as prisões ilegais, a tortura, a extorsão e o estupro, pois o que se pretendia era apenas camuflar a permanência do regime então vigorante de impunidade. Talvez, também, na expectativa de que o homicídio doloso obtivesse dos tribunais do juri a costumeira benevolência.

Apreciando o projeto, já no Senado, o então senador Cid Sabóia, que primeiro relatou a proposição, considerou sem maior sentido a restrição nele contida de apenas atribuir à competência da Justiça Comum o julgamento dos crimes dolosos contra a vida, mas submeteu-se à fórmula aprovada na Câmara dos Deputados, pela urgência, segundo dizia, em retirarse, desde logo, da competência da Justiça militar os homicídios dolosos. Mas em seu parecer, já admitia a necessidade de complementar-se essa decisão mediante a apresentação de novo projeto que viesse a ampliar a proposta que então submetia à Casa. Contudo, o projeto não teve andamento até que se nomeou o senador Roberto Freire para novo parecer. Este senador tentou restabelecer a idéia original contida no substitutivo apresentado na Câmara dos Deputados, que delatava os limites da competência da Justiça Comum, mas foi mais uma vez vencido na Comissão de Constituição e Justiça, pelo poderoso lobby das Polícias Militares...

Diante disso, apresentou-se ainda à Câmara um novo projeto, com a necessária abrangência, buscando solucionar outros problemas na equação civil-militar, não só os que desembocavam na impunidade, mas também 
considerados relevantes no equacionamento da matéria. A esse projeto as lideranças partidárias determinaram a urgência na sua tramitação, oportunidade em que o próprio Executivo federal procurou dar sua contribuição, surgindo dessa intervenção a redação final aprovada em votação nominal nos últimos dias de janeiro de 1995.

No Senado, a nova proposta teve tramitação urgente por solicitação da presidência da República. Aproveitou-se, contudo, da urgência para recusar o projeto e reativar o anterior, que acabou sendo aprovado, referendado pela Câmara e promulgado, transformando-se na lei n ${ }^{\circ} .9 .299$ de 7 de agosto de 1996.

O então senador Élcio Álvares, líder do governo, manobrou no sentido de abortar o projeto em questão para aprovar o anterior, retirado da gaveta onde então se encontrava. Esse projeto foi aprovado com alterações inaceitáveis, recusadas, afinal, pela Câmara, que aprovou, para evitar o mal maior, o projeto anterior, como subira ao Senado.

Posteriormente, apresentou-se um novo projeto na tentativa de racionalizar, ainda uma vez, essa questão de competência para o processo e julgamento dos crimes chamados de policiamento. Esse projeto teria passado tranqüilamente na Câmara dos Deputados não fosse a interferência do então assessor jurídico da presidência da República, o procurador federal Gilmar Mendes, ao formular proposta que ressuscitaria a Justiça militar das PMs na sua maior amplitude. Diante disso, as lideranças da Câmara acordaram num substitutivo que, parcialmente, atendia ao interesse público, mas permaneciam ainda no âmbito das Polícias Militares as apurações dos fatos delitivos praticados por milicianos. Com uma redação bastante defeituosa, o projeto foi aprovado na Câmara e remetido ao Senado. Neste, o então senador Josaphat Marinho ofereceu substitutivo, recuperando a idéia inicial de maior abrangência da justiça comum na investigação e no processo e julgamento dos crimes em questão. Não se sabe bem por que, mas é possível imaginar o que aconteceu: o senador Josaphat Marinho perdeu a relatoria na Comissão de Constituição e Justiça e o projeto foi entregue ao senador Edson Lobão que, pura e simplesmente, o engavetou. Redistribuído ao senador Iris Rezende, até hoje não se tem notícia do que aconteceu...

Este é apenas um dos aspectos da questão, quando se nota, o que depois se confirmou, o pouco ou nenhum interesse do governo federal em alterar o sistema policial, como um todo.

Ora, tendo em vista que o modelo de segurança pública oriundo da ditadura militar está inteiramente esgotado e não se sabe mesmo como a 
Constituição cidadã de 1988 o encampou, ofereceu-se, em 1992, à Câmara dos Deputados, projeto de emenda com o devido apoiamento legal, unificando as polícias num só organismo civil, com um segmento uniformizado para as funções de policiamento ostensivo e outro em trajes civis, para a problemática investigativa, com unidade de comando e carreira única, ensejando ao policial que deve iniciar suas atividades na rua, a possibilidade de alcançar - o que hoje não acontece - os postos mais altos da corporação policial, naturalmente depois de capacitar-se em cursos intermediários oferecidos pela própria polícia.

Esse projeto de emenda, que recebeu parecer favorável na Comissão de Constituição e Justiça da Câmara dos Deputados, não prosperou na Comissão Especial encarregada, segundo o Regimento Interno daquela Casa, de estudá-la, aprovando ou não, para, em conseqüência, submetê-la à votação no Plenário. Isto se deveu, substancialmente ao lobby misto PM/Exército, que impôs, primeiro, nomes comprometidos com a recusa do projeto, e depois o parecer do relator para rejeitá-lo. Para se constatar o que se acaba de afirmar, basta verificar os nomes que fizeram parte da aludida Comissão, a maioria comprometida com a estrutura atual da polícia. Recusada a emenda na Comissão, não foi levada a Plenário.

Posteriormente, o presidente da República, tendo em vista ante-projeto oferecido pelo governo do estado de São Paulo (Mário Covas), encaminhou nova emenda unificadora, entretanto, sem revelar por ela maior interesse, essa emenda caiu no esquecimento. Chegou-se a criar uma espécie de comissão especial, sem as qualificações legais indispensáveis para o normal andamento da emenda. As conclusões a que se chegou, apenas num exercício especulativo, caíram, também, no esquecimento. A situação permaneceu, pois, inalterada.

Não obstante, ultimamente, com a iniciativa das ouvidorias de polícia, juristas de São Paulo ofereceram à consideração dos Poderes Executivo e Legislativo um fundamentado projeto de emenda criando uma polícia única, com unidade de comando de caráter civil, emenda que contém os passos necessários à sua organização, determinando a instituição de uma verdadeira carreira unificada, com acesso condicionado ao permanente aperfeiçoamento do policial.

Vejamos. O projeto põe fim à dualidade na função policial, extinguindo as Polícias Civis e Militares dos estados, criando uma Polícia Estadual, instituída no prazo de dois anos a partir da extinção dos atuais corpos policiais. Em conseqüência, extinguem-se os tribunais e auditorias militares estaduais, submetendo-se, todos os policiais, à competência da Justiça Comum. 
A nova polícia na conformidade proposta terá cinco graus hierárquicos, com um teto salarial máximo e mínimo, respeitando a diferença máxima de quatro vezes o menor salário.

Extingue-se, por outro lado, a fase inquisitorial do procedimento penal, ou seja, o inquérito policial, passando a investigação criminal a ser de responsabilidade do Ministério Público, que irá orientá-la, deixando porém o deslinde de crimes e a identificação de seus autores aos técnicos da polícia e aos setores científicos da criminalística, estes organizados em carreiras enquadradas no corpo funcional do Poder Judiciário.

Os corpos de bombeiros passarão a fazer parte do sistema de defesa civil, como, aliás, já acontece em vários estados da Federação.

O projeto permitirá que se aumente o número de policiais nas ruas, com melhor utilização de seu efetivo, instalações e equipamentos, tendo como conseqüência um melhor resultado na relação custo/benefício.

Com uma única escola de formação, com a realização de cursos de aperfeiçoamento e reciclagem de pessoal, a nova polícia será especificamente civil, pondo-se um ponto final à sua formação autoritária. Com esse modelo, encerrar-se-á aquele concebido para atuar no controle social da população mais pobre, excluída ou marginalizada, para uma polícia democrática, subordinada ao Poder civil.

Entretanto, não obstante o lançamento do Plano Federal de Segurança Pública, em maio deste ano (2000), não se fez a menor alusão à proposta. Prevaleceu o comodismo que, no caso, é o grande culpado pela permanência de um órgão público responsável por parcela apreciável da violência no país, seja pela impropriedade de sua atuação, seja pelas distorções geradoras dessa mesma violência.

Uma polícia criada para o enfrentamento bélico não poderia trazer senão índices cada vez maiores de violência contra os segmentos mais discriminados da sociedade, como os meninos e meninas de rua, os pobres, os negros, os homossexuais e toda a sorte de excluídos.

A recente pesquisa realizada em São Paulo, pela sua ouvidoria de polícia mostra o seguinte quadro: as eliminações pela Polícia Militar chegaram a $1.421 \mathrm{em} \mathrm{1992.} \mathrm{Decresceram} \mathrm{a} \mathrm{partir} \mathrm{daí,} \mathrm{caindo} \mathrm{para} \mathrm{seu} \mathrm{número} \mathrm{mais}$ baixo em 1993 (377). Daí em diante, oscilou entre 592 (1995) e 577 (1999), o que talvez se deva aos movimentos pela reforma do aparelho de segurança que ocorreram nesse período. Explico-me: diante das alterações propostas nesses quadros, a retirar o poder que os transformaram em verdadeiros "po- 
deres paralelos" aos próprios governos estaduais, arrefeceu-se o seu ímpeto, para aparentar a aceitação de uma nova política que valoriza os direitos humanos. Todavia, a partir do instante em que novas perspectivas de mudança não ocorriam, pois o projeto sobre a ampliação da competência da Justiça Comum, para o julgamento de policiais militares que tivessem cometido crimes de policiamento estava e está engavetado no Senado Federal - e a chamada reforma do Poder Judiciário incorpora a Justiça Militar das Polícias Militares dos estados como órgão desse Poder e com isso anula os avanços obtidos na supressão da competência da Justiça militar das PMs para o processo e julgamento dos crimes de policiamento -, os números pularam para 489 , somente no primeiro semestre deste ano (2000), o que indica um crescimento de $77 \%$ com relação à mesma época do ano anterior. Dessas mortes, 449 são de autoria da Polícia Militar e 40 imputadas à Polícia Civil.

Permanecendo a média, poderemos chegar, ao final do ano com cerca de mil mortos, marca que não tínhamos em São Paulo, desde 1992.

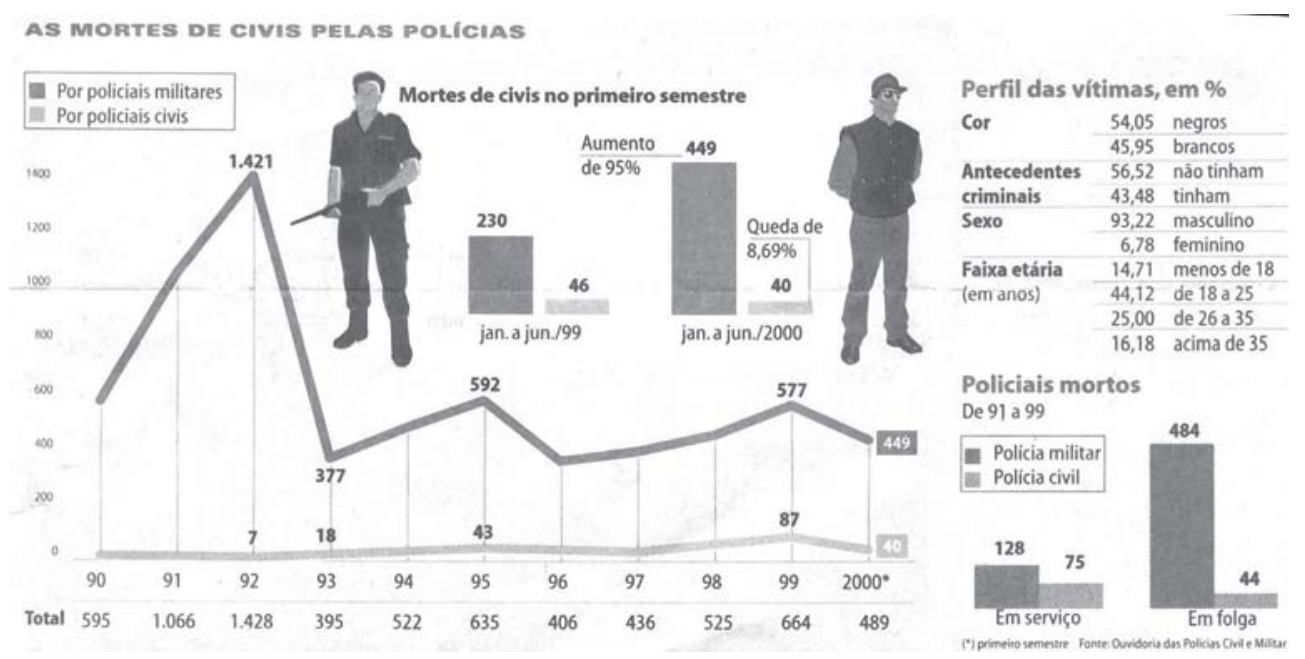

${ }^{*}$ ) primeiro semestre

Fonte: Ouvidoria das polícias civil e militar, publicado no jornal Folha de S. Paulo, Caderno Cotidiano, 17 jul. 2000.

Por outro lado, as estatísticas nacionais demonstram a "preferência" da polícia pelos excluídos: em 1997 foram eliminados 1.396 marginalizados no país, número que cresceu para 2.986, no ano seguinte.

Meninos e meninas entre 10 e 19 anos também compõem um contingente apreciável. De 457 homicídios nessa faixa etária em 1997, passaram para 737 em 1998. 
Os negros ganharam longe nessa macabra competição: de 290, em 1997, vão para 614 no ano seguinte.

Os homens compõem o maior contingente: de 2.028 eliminados em 1997, passam para 3.157 em 1998. Quanto às mulheres, os índices são bem mais baixos: em 1997 são eliminadas 1.054 mulheres, número que vai para $1.327 \mathrm{em} 1998$.

Como se vê, o poderio de nossa polícia - a que tem maior efetivo é a militar, com mais de 300 mil homens distribuídos pelos vários estados da Federação - volta-se contra a população mais humilde e marginalizada. E isto decorre, sem dúvida, da vocação da Polícia Militar, institucionalmente organizada para atuar com violência na sustentação de um Estado de viés autoritário.

A mudança que se impõe aparece clara aos olhos de quantos querem ver. Entretanto, como aqueles que preferem não ver detêm os cordéis do Poder, vamos ficando com uma polícia que não oferece ao povo senão insegurança e violência.

Hélio Bicudo é advogado e jornalista. Foi promotor-público, procurador da Justiça em São Paulo e chefe de gabinete do ministro da Fazenda Carvalho Pinto (1963). Membro-fundador da Comissão Justiça e Paz de São Paulo e membro da Comissão Teotônio Vilela de Direitos Humanos. Deputado Federal pelo PT-SP (19901998). É autor, entre outros, dos livros Do esquadrão da morte aos justiceiros (1988), Violência: o Brasil cruel e sem maquiagem (1994), Direitos humanos e sua proteção (1998). 